Working for the West?

\section{London}

NPO Vector, a large biotechnology research and production complex in Novosibirsk, linked to the Siberian Academy of Sciences, will sign its first business deal with the West within the next month in an agreement to sell its products through a British company, Oxford Virology. The agreement signals the arrival in Siberia of a trend that began three years ago in Moscow when the Institute of Molecular Genetics attempted to forge the first Soviet links with foreign biotechnology companies

That institute and the M.M. Shemyakin Institute of Bioorganic Chemistry in Moscow are the leaders in the field, but very few of the discussions that Soviet researchers have had with foreign companies have led to productive collaboration. Research and development projects that require Western companies to operate within the Soviet Union have been the least successful, as laws for the operation of foreign businesses are still not fully developed.

The Siberian collaboration may do better as it involves only the marketing of Soviet products. But even this kind of agreement may run into difficulties, according to Professor Valery Soyfer, a Soviet molecular biologist now at George Mason University, Virginia. Although such agreements are very important for Soviet biotechnology, says Soyfer, with the potential to bring in badly needed hard currency, the Soviet economy is "so deeply ill" that Soviet partners may be unable to guarantee the supply of products.

John Meers, chief executive of Enzyma-

\section{IMAGE UNAVAILABLE FOR COPYRIGHT REASONS}

One of NPO Vector's more unusual products is fetal reindeer serum. Free-ranging Siberian reindeer have never been exposed to antibiotics and so can provide a culture medium that has none of the anitbiotic contamination problems of the commonly-used fetal calf serum. But persuading Western scientists to risk their valuable cell cultures in an unfamiliar medium will be difficult. More realistic money-earners will be NPO Vector's range of virus insecticides and antiviral agents. tix, a small Cambridge-based company, says there are also problems with the quality of some Soviet products. Enzymatix and some other British companies have taken a different route and licensed Soviet-developed technology to manufacture biological products in the United Kingdom. Only a few companies have so far chosen to set up joint research and development ventures with Soviet institutes. One of the largest such projects is a research laboratory and production plant at the Shemyakin Institute, set up last year by the US pharmaceutical company Monsanto and MNTK Biogen, a technology transfer organization established in 1986 to promote the commercial application of Soviet biotechnology research. The low costs of Soviet research is the principal attraction to big Western companies. Another motivation is the desire to gain a foothold in the Soviet market, according to Rod Greenshields, managing director of GB Biotechnology.

In other disciplines, there are worries that increasing links with Western companies may divert Soviet scientists from innovative work. But commercial collaboration with the West in biotechnology is at such an early stage, says Professor Maxim Frank-Kamenetskii, from the Institute of Molecular Genetics in Moscow, that increased links can have only a positive effect on Soviet biotechnology in the short term.

The most pressing problem for academy institutes, he says, is the 'brain drain' of young scientists to the West, which may be slowed by an influx of Western finance.

Peter Aldhous

\title{
Psychiatric abuses revealed
}

\section{Munich}

IN a case that has cast a shadow over the psychiatric profession in the unified Germany, the East German Volkskammer (parliament) has recommended criminal charges against psychiatrists working in the East German psychiatric clinic at Waldheim (near Dresden) who performed castrations and brain operations on at least a dozen patients against their will.

Although only three physicians were implicated directly, a special committee of the Volkskammer reported that stateemployed psychiatrists across East Germany abused their professional status by revealing data about their patients to the Stasi (secret police). Stasi also issued orders to psychiatrists to detain healthy people in mental institutions in an attempt to prevent public protests, the committee reported.

The Volkskammer also recommended that the all-German parliament (Bundestag) should continue an investigation into abuses by East German psychiatrists at Waldheim and elsewhere. The case has psychiatric professionals in both parts of Germany worried about the medical credentials of their East German colleagues. The credentials of physicians trained in East Germany are generally accepted without question in the western part of Germany.

The Volkskammer considered the committee report important enough to squeeze it into the legislative calendar after midnight on the last day of East Germany's separate existence before German unificaiion on 3 October. Extracts from the report, which has not yet been released to the public, were published in the West German newspaper Frankfurter Allgemeine Zeitung.
In the twelve most serious cases discovered so far, patients were castrated using X-rays or lobotomized or had parts of their brains heated, killing large numbers of cells. Other patients were reported to have been "quieted" through excessive exercise or through prolonged incarceration in small, unlit cells.

The Waldheim clinic, which unlike other East German psychiatric hospitals was attached to a prison, has been described as a kind of alternative jail for difficult inmates. Other psychiatric hospitals, such as one in nearby Hochweitschen, are also thought to have acted as a jail for citizens who were expected to become "agitators" at state-arranged demonstrations. A Waldheim city councilman was temporarily committed to Hochweitschen in 1983 as a punishment for trying to correspond with US President Ronald Reagan.

In order to find out if there were more widespread abuses, psychiatrists in both parts of Germany are urging the German Health Ministry to sponsor an investigation into conditions in psychiatric hospitals in the eastern part of Germany.

A delegation urging an investigation led by the Bonn-based 'Aktion Psyschich Kranke' (APK or Action for the Mentally III) was given a favourable reception earlier this year by West German Health Minister Ursula Lehr. But Manfred Bauer, an APK executive committee member, says that the Bonn government has since shed responsibility for any investigation on the grounds that the Länder (states), not Bonn, are responsible for an investigation. It is too early to say whether the Bundestag itself will now investigate Waldheim as a result of the Volkskammer report. Steven Dickman 